\title{
Objective and Sensory Evaluation of Fresh Fruit of Day-neutral Strawberry Cultivars
}

\author{
Cheryll A. Reitmeier ${ }^{1}$ and Gail R. Nonnecke ${ }^{2}$ \\ Iowa State University, Ames, IA 50011 \\ Additional index words. Fragaria $\times$ ananassa, color, firmness, quality
}

\begin{abstract}
Sensory and objective attributes of fresh fruit of five locally grown dayneutral strawberry (Fragaria $\times$ ananassa Duch.) cultivars (Tristar, Tribute, Mrak, Yolo, and Selva) were compared to those of California-grown strawberries available in the Iowa markets. 'Tristar' and 'Tribute' fruit were redder and more sour than fruit of other day-neutral cultivars, and 'Tristar' fruit were the most juicy of the berries evaluated. 'Tristar' and 'Tribute' fruit had higher titratable acidity and lower Hunter L (lightness) values than those of other evaluated fruit. Sensory panelists rated the California-grown berries as the least red.
\end{abstract}

Day-neutral strawberry cultivars have been introduced as strawberries capable of producing high quality fruit throughout the growing season (Draper et al., 1981). A longer season of production would benefit growers because of higher yields and higher out-ofseason prices. Consumers may benefit from locally grown fruit that may be higher quality and more flavorful than those grown elsewhere. Preliminary marketing analysis of dayneutral strawberries indicated that Iowa con-

Received for publication 4 Sept. 1990. Journal Paper no. J-14115 of the Iowa Agriculture and Home Economics Experiment Station, Ames. Profect no. 2808. This work was supported in part by funding from the Iowa State Univ. Achievement Foundation. We acknowledge the technical assistance of Lynne Doerselmna, graduate student in food science. The cost of publishing this paper was defrayed in part by the payment of page charges. Under postal regulations, this paper therefore must be hereby marked advertisement solely to indicate this fact.

'Dept. of Food Science and Human Nutrituition. ${ }^{2}$ Dept of Horticulture. sumers preferred the flavor of locally available day-neutral cultivars compared with berries transported from out-of-state regions (Nonnecke and Hayenga, 1989).

The objectives of our study were to 1) compare the sensory characteristics of five day-neutral strawberry cultivars with strawberries available in a supermarket during late summer, and 2) determine the physical and chemical characteristics of the day-neutral cultivars.

Five day-neutral strawberry cultivars (Tristar, Tribute, Mrak, Yolo, Selva) were

Table 1. Harvest dates for day-neutral strawberry cultivars.

\begin{tabular}{lccccccc}
\hline \hline & \multicolumn{7}{c}{ Date $^{\mathrm{z}}$} \\
\cline { 2 - 8 } Cultivar & $\mathbf{1}$ & 2 & 3 & 4 & 5 & 6 & 7 \\
\hline Tristar & $\mathrm{X}$ & $\mathrm{X}$ & $\mathrm{X}$ & $\mathrm{X}$ & $\mathrm{X}$ & $\mathrm{X}$ & $\mathrm{X}$ \\
Tribute & 0 & $\mathrm{X}$ & $\mathrm{X}$ & $\mathrm{X}$ & $\mathrm{X}$ & $\mathrm{X}$ & $\mathrm{X}$ \\
Mrak & $\mathrm{X}$ & $\mathrm{X}$ & 0 & $\mathrm{X}$ & 0 & $\mathrm{X}$ & $\mathrm{X}$ \\
Yolo & $\mathrm{X}$ & $\mathrm{X}$ & 0 & $\mathrm{X}$ & 0 & $\mathrm{X}$ & $\mathrm{X}$ \\
Selva & $\mathrm{X}$ & 0 & 0 & 0 & 0 & $\mathrm{X}$ & $\mathrm{X}$ \\
\hline
\end{tabular}

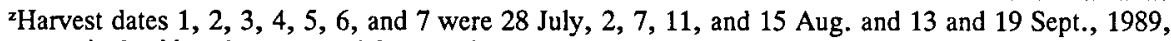
respectively. $X=$ harvest, and $0=$ no harvest. grown following standard horticultural practices at the Iowa State Univ. Horticulture Station, Ames, during the 1989 season. Harvest dates and frequency of harvest are listed in Table 1. California-grown strawberries (Driscoll Strawberry Assocs., Watsonville, Calif.) were purchased from a commercial establishment at each of the seven harvest dates. The California-grown fruit represents the strawberries available locally in August and September, and was not the same cultivar as any of the Iowa-grown cultivars.

Two kilograms of each cultivar was harvested at the red-ripe stage, transported to the Dept. of Food Science and Human Nutrition, washed, and sorted. Berries of 2 to $2.5 \mathrm{~cm}$ diameter were selected for sensory evaluation, and berries of 2.5 to $4 \mathrm{~cm}$ diameter were selected for firmness measurements. Remaining berries (a mixture of both sizes) were used for $\mathrm{pH}$, soluble solids concentration (SSC), titratable acidity, and color measurements. The berries were not refrigerated, and all evaluations were completed within $6 \mathrm{~h}$ after harvest.

California-grown strawberries were evaluated for firmness, $\mathrm{pH}, \mathrm{SSC}$, titratable acidity, and color following procedures described for the Iowa-grown cultivars. The California-grown berries had been refrigerated in transport and in the market.

About $100 \mathrm{~g}$ of berries of each cultivar was decapped and blended for $1 \mathrm{~min}$ in a blender. Five grams of puree was diluted to $100 \mathrm{ml}$ with deionized water, titrated to $\mathrm{pH}$ 
Table 2. Objective attributes of California-grown strawberries and lowa-grown day-neutral strawberry cultivars. ${ }^{2}$

\begin{tabular}{|c|c|c|c|c|c|c|c|c|c|c|}
\hline \multirow[b]{3}{*}{ Cultivar ${ }^{y}$} & \multirow[b]{3}{*}{$\mathrm{pH}$} & \multirow{3}{*}{$\begin{array}{c}\text { Titratable } \\
\text { acidity }^{\mathbf{x}} \\
(\%)\end{array}$} & \multirow{3}{*}{$\begin{array}{l}\mathrm{SSC} \\
(\%)\end{array}$} & \multicolumn{5}{|c|}{ Color $^{w}$} & \multirow{2}{*}{\multicolumn{2}{|c|}{ Firmness $^{v}(\mathrm{~N})$}} \\
\hline & & & & \multirow[b]{2}{*}{$\mathrm{L}$} & \multirow[b]{2}{*}{ a } & \multirow[b]{2}{*}{$\mathbf{b}$} & \multirow{2}{*}{$\begin{array}{c}\text { Hue } \\
\text { angle }\end{array}$} & \multirow{2}{*}{$\begin{array}{l}\text { Saturation } \\
\text { index }\end{array}$} & & \\
\hline & & & & & & & & & Skin & Flesh \\
\hline California-grown & $3.54 \mathrm{bc}$ & $0.85 \mathrm{a}$ & $8.9 \mathrm{a}$ & $33.2 \mathrm{e}$ & $28.1 \mathrm{a}$ & $11.9 \mathrm{bc}$ & $23.2 \mathrm{c}$ & $30.6 \mathrm{a}$ & 4.02 & $6.37 \mathrm{abc}$ \\
\hline Tristar & $3.38 \mathrm{a}$ & $1.10 \mathrm{~b}$ & $9.4 \mathrm{ab}$ & $22.6 \mathrm{a}$ & $32.7 \mathrm{c}$ & $11.5 \mathrm{ab}$ & $19.4 \mathrm{a}$ & $34.6 \mathrm{c}$ & 3.43 & $5.88 \mathrm{a}$ \\
\hline Tribute & $3.45 \mathrm{a}$ & $1.18 \mathrm{~b}$ & $8.0 \mathrm{a}$ & $24.2 \mathrm{~b}$ & $32.9 \mathrm{c}$ & $12.0 \mathrm{bc}$ & $20.0 \mathrm{ab}$ & $35.0 \mathrm{c}$ & 3.73 & $7.06 \mathrm{~cd}$ \\
\hline Mrak & $3.63 \mathrm{c}$ & $0.85 \mathrm{a}$ & $10.4 \mathrm{~b}$ & $28.7 \mathrm{~d}$ & $31.5 \mathrm{bc}$ & $11.9 \mathrm{bc}$ & $20.8 \mathrm{ab}$ & $33.6 \mathrm{bc}$ & 3.33 & $5.98 \mathrm{ab}$ \\
\hline Yolo & $3.54 \mathrm{bc}$ & $0.89 \mathrm{a}$ & $10.8 \mathrm{~b}$ & $26.9 \mathrm{c}$ & $30.3 \mathrm{~b}$ & $11.1 \mathrm{a}$ & $20.1 \mathrm{ab}$ & $32.7 \mathrm{~b}$ & 3.63 & $6.28 a b c$ \\
\hline Selva & $3.61 \mathrm{c}$ & $0.84 \mathrm{a}$ & $8.8 \mathrm{a}$ & $29.3 d$ & $31.4 \mathrm{bc}$ & $12.2 \mathrm{c}$ & $21.3 \mathrm{~b}$ & $33.7 \mathrm{bc}$ & 3.82 & $7.65 \mathrm{~d}$ \\
\hline
\end{tabular}

${ }^{2}$ Mean separation within columns, $P<0.05$. Lack of letters $=$ differences nonsignificant.

${ }^{y}$ Califonia-grown strawberries (cultivar unknown) were purchased from a commercial source; day-neutral cultivars were grown at Iowa State Univ., Horticulture Station, Ames.

${ }^{\mathrm{x}}$ Expressed as percent citric acid by titration of $5 \mathrm{~g}$ puree to $\mathrm{pH} 7$ with $0.1 \mathrm{~N} \mathrm{NaOH}$.

${ }^{w}$ Standardized with Hunter $\mathrm{L}=34.2, \mathrm{a}=50.2$ and $\mathrm{b}=20.9$; hue angle $=\tan ^{-1} \mathrm{~b} / \mathrm{a}$, saturation index $=\left[\left(\mathrm{a}^{2}+\mathrm{b}^{2}\right)^{1 / 2}\right]$.

"Instron Universal Testing Machine $(\mathrm{kgf} \times 9.8=\mathrm{N})$.

Table 3. Sensory characteristics of California-grown strawberries and Iowa-grown day-neutral strawberry cultivars. ${ }^{2}$

\begin{tabular}{lcccccc}
\hline \hline & \multicolumn{5}{c}{ Sensory characteristics } \\
\cline { 2 - 7 } Cultivar $^{\mathbf{x}}$ & Color & Firmness & Juiciness & Sourness & Sweetness & Flavor \\
\hline California-grown & $8.5 \mathrm{a}$ & 8.4 & $9.8 \mathrm{a}$ & $7.2 \mathrm{~b}$ & $5.8 \mathrm{a}$ & $7.4 \mathrm{a}$ \\
Tristar & $13.9 \mathrm{c}$ & 7.9 & $11.4 \mathrm{c}$ & $9.3 \mathrm{c}$ & $6.7 \mathrm{ab}$ & $9.1 \mathrm{~b}$ \\
Tribute & $13.0 \mathrm{c}$ & 8.9 & $10.9 \mathrm{bc}$ & $10.3 \mathrm{c}$ & $5.7 \mathrm{a}$ & $8.5 \mathrm{ab}$ \\
Mrak & $10.7 \mathrm{~b}$ & 7.1 & $9.3 \mathrm{a}$ & $5.5 \mathrm{a}$ & $7.3 \mathrm{~b}$ & $8.1 \mathrm{ab}$ \\
Yolo & $11.1 \mathrm{~b}$ & 8.0 & $10.1 \mathrm{ab}$ & $6.1 \mathrm{ab}$ & $7.8 \mathrm{~b}$ & $9.1 \mathrm{~b}$ \\
Selva & $10.3 \mathrm{~b}$ & 9.2 & $8.9 \mathrm{a}$ & $6.2 \mathrm{ab}$ & $6.8 \mathrm{ab}$ & $7.0 \mathrm{a}$ \\
& & NS & & & & \\
\hline
\end{tabular}

${ }^{2}$ Means of 12 panelists. Mean separation within columns, $P<0.05$. Lack of letters $=$ differences nonsignificant.

$y_{0}=$ green, mushy, extremely dry, no sourness, no sweetness, and no fruit flavor; $17=$ deep red, extremely firm, extremely intense sourness, extremely intense sweetness, and extremely intense fruit flavor.

${ }^{\times}$California-grown strawberries (cultivar unknown) were purchased from a commercial source; day-neutral cultivars were grown at Iowa State Univ., Horticulture Station, Ames.

7.0 with $0.1 \mathrm{~N}$ sodium hydroxide, and reported as percentage of citric acid.

SSC (percent) was determined by extruding a sample of puree through two layers of tissue paper onto the lens of a Reichert-Jung refractometer ( $\left.0-50{ }^{\circ} \mathrm{Brix}\right)$. The $\mathrm{pH}$ of strawberry puree of each cultivar was measured with a Fisher (Model 640A) pH meter.

The color of strawberry puree of each cultivar was measured with a Hunter (D-25) Tristimulus Colorimeter (Hunter Assocs. Lab., Reston, Va.) standardized with a red tile (no. C20-2224, L = 34.2, a = 50.2, b $=20.9)$. Puree $(\approx 40 \mathrm{ml})$ was poured into a standard (Hunter) glass container, and L, a, and $b$ measurements were recorded. Hue angle $\left(\tan ^{-1} b / a\right)$ and saturation index $\left[\left(a^{2}+b^{2}\right)^{1 / 2}\right]$ were calculated (Clydesdale, 1978; Setser, 1984).

Duplicate measurements of titratable acidity percentage, $\mathrm{SSC}, \mathrm{pH}$, and color of each cultivar were completed at each harvest date.

The firmness of ten ripe berries of each cultivar was measured with an Instron Universal Testing Machine (Model 1122; Instron, Canton, Mass.) by using a star-shaped (five-point, 1-cm-diam) probe penetrating the side of the berry with the stem in a horizontal plane (Ourecky and Bourne, 1963). Each strawberry was placed on a plate with a 1.5$\mathrm{cm}$ opening. A load cell setting of $50 \mathrm{~kg}$, a crosshead speed of $500 \mathrm{~mm} \cdot \mathrm{min}^{-1}$, and a chart speed of $200 \mathrm{~mm} \cdot \mathrm{min}^{-1}$ were used. The probe moved through the entire berry. The amounts of force (kgf) to break the skin and to puncture the flesh and core were expressed in Newtons. A mean of 10 measurements was used to determine firmness values for each cultivar at each harvest.

Sensory evaluation of strawberries was completed by a 12-member trained sensory panel according to procedures described by Heintz and Kader (1983). Panelists were presented berries from several cultivars and a range of degrees of ripeness in six training sessions during June and July. Panel members were selected from students, staff, and faculty at Iowa State Univ.

At each harvest date, washed ripe berries with attached sepals were used for evaluation of the local day-neutral cultivars and California-grown strawberries. Two randomly selected berries of each cultivar were placed into individual styrofoam cups and coded with randomly selected three-digit numbers. Panelists were in individual booths and were instructed to rinse their mouths with water between samples. Unsalted crackers were also provided.

Panelists received samples of each cultivar and were instructed to sample randomly. They were instructed to grasp the berry at the stem end and bite through the middle of the berry. A 17-cm line scale was used to evaluate color, firmness, juiciness, sourness, sweetness, and fruit flavor. Green, mushy, extremely dry, no sourness, no sweetness, and no fruit flavor were scored 0; deep red, extremely firm, extremely juicy, extremely intense sourness, extremely intense sweetness, and extremely intense fruit flavor were scored 17.

The data were analyzed based on a completely randomized design. Analysis of variance was used (general linear model, PROC GLM) to test effects of cultivar (SAS, 1985). Analysis of physical and chemical data for each cultivar was conducted on the unweighed means for each harvest date and cultivar. Sensory data were analyzed with unweighed means averaged over harvest dates and panelists. When $\mathrm{F}$ values were significant, least significant differences (LSD) at $P=0.05$ were calculated.

The $\mathrm{pH}$ of 'Tristar' and 'Tribute' fruit was lower than that of California-grown fruit or that of 'Yolo', 'Selva', and 'Mrak' Iowa fruit (Table 2). Titratable acidity of 'Tristar' and 'Tribute' cultivars was higher than that of California-grown or local 'Mrak', 'Yolo', and 'Selva' fruit. Fruit of 'Mrak' and 'Yolo' had a higher SSC than fruit of California-grown strawberries or Iowa-grown 'Tribute' and 'Selva' strawberries.

Hunter $\mathrm{L}$ values indicated that Californiagrown fruit was the lightest $(\mathrm{L}=33.2)$ followed by 'Selva' and 'Mrak', 'Yolo', 'Tribute', and 'Tristar', respectively (Table 2). 'Tristar' and 'Tribute' fruit had the highest Hunter a values, indicating the most intense red color, while the California-grown fruit had the lowest 'a' value. The Hunter a value is a reliable test for redness among strawberry cultivars (Sistrunk and Morris, 1985). Sistrunk and Moore (1979) reported that strawberry selections containing $\geq 0.8$ titratable acidity and high Color Difference Meter 'a' values were rated higher in quality attributes by a sensory panel. In a similar study, high acidity and low $\mathrm{pH}$ values were found to stabilize strawberry color in frozen fruit (Sistrunk and Morris, 1985).

Hue angle is the relation of Hunter a (redness) to Hunter b (yellowness) (Setser, 1984). Fruit of 'Tristar', 'Tribute', 'Mrak', 'Yolo', 
and 'Selva' were similar in redness (Table 2). The California-grown fruit was the least red of all cultivars compared. Differences in redness by hue angle values were not as great as indicated by Hunter a values.

The saturation index (S.I.) or chroma for California-grown fruit was lower than the S.I. values for the Iowa-grown day-neutral cultivars (Table 2). The S.I. values for 'Tristar', 'Tribute', 'Mrak', and 'Selva' were similar.

The amount of force required to puncture the skin of the berries was similar among cultivars. The internal flesh and core, as a unit, of 'Selva' fruit was firmer than that of all berries but 'Tribute'.

The sensory evaluation results for color, firmness, sourness, and sweetness correspond well with the color measurements, Instron firmness, titratable acidity, and SSC, respectively.

Sensory panelists judged 'Tristar' and 'Tribute' fruit to be the most intensely red cultivars (Table 3). California-grown fruit was the least red. Luby et al. (1987) reported that 'Tribute' and 'Tristar' fruit had higher sensory color scores (7. 1 and 7.0, respectively) than did the reference California-grown strawberry (6.2). Draper et al. (1981) also described the skin color of 'Tristar' and 'Tribute' as a glossy deep red.

Sensory firmness values among berries were similar. Luby et al. (1987) reported that 'Selva' fruit were rated fair (5.8) and 'Tristar' and 'Tribute' were rated good (6.7 and 6.9 , respectively) in texture $16 \mathrm{~h}$ after harvest, but 'Tristar' and 'Tribute' were not different from the reference California-grown sample (6.4).

Sensory panelists rated 'Tristar' and 'Tribute' fruit as the most juicy and the most sour (Table 3). Luby et al. (1987) also reported that 'Tribute' and 'Tristar' fruit were described as tart by sensory panelists.

Sweetness and flavor were perceived as similar among the strawberry cultivars, but California-grown and 'Selva' fruit had less fruit flavor than 'Tristar' or 'Yolo' (Table 3). Luby et al. (1987) reported lower flavor scores for 'Selva' (4.9) compared with a reference sample (6.0), 'Tristar' (6.7), and 'Tribute' (6.5). Strawberries with desirable redness and with a good balance of acidity and sugars usually are rated high in flavor quality by sensory panels (Sistrunk and Morris, 1985).

The quality of Iowa-grown day-neutral cultivars used in this study rated favorably when compared with the California-grown strawberries available in markets in August and September. The results of this study suggest that locally grown fruit should be able to compete in the market with Californiagrown strawberries. Additional research on day-neutral cultivars should consider storage quality and consumer attitudes about strawberries that are redder and tarter than California fruit available in the supermarket.

\section{Literature Cited}

Clydesdale, F.M. 1978. Colorimetry-methodology and applications. CRC Crit. Rev. Food Sci. Nutr. 10:243-301.
Draper, A.D., G.J. Galletta, and H.J. Swartz. 1981. 'Tribute' and 'Tristar' everbearing strawberries. HortScience 16:794-795.

Heintz, C.M. and A.A. Kader. 1983. Procedures for the sensory evaluation of horticultural crops. HortScience 18:18-22.

Luby, J.J., S.T. Munson, and E.E. Hoover. 1987. Sensory evaluation of fresh and frozen fruit from day-neutral strawberry cultivars. Adv. Strawberry Prod. 6:11-13.

Nonnecke, G.R. and M.L. Hayenga. 1989. Studies concerning the economic feasibility of producing and marketing day-neutral strawberries in the Midwest. A final report. U.S. Dept. Agr. Federal State Marketing Imp. Program, Washington, D.C.
Ourecky, D.K. and M.C. Bourne. 1963. Measurement of strawberry texture with an Instron machine. Proc. Amer. Soc. Hort. Sci. 93:317325.

Setser, C.S. 1984. Color Reflections and transmissions. J. Food Qual. 6: 183-197.

Sistrunk, W.A. and J.N. Moore. 1979. Evaluating strawberry selections and cultivars for processing. Arkansas Farm Res. 28(1):7.

Sistrunk, W.A. and J.R. Morris. 1985. Strawberry quality Influence of cultural and environmental factors, p. 217-256. In: H.E. Pattee (ed.). Evaluation of quality of fruits and vegetables. AVI, Westport, Conn.

SAS Institute. 1985. SAS user's guide: Statistics. SAS Institute, Inc., Cary, N.C. 